\title{
Exegesis Methodology of Al-Maturidi
}

\author{
Assistant Prof. Dr. Ömer Faruk Bilgin \\ Bursa Uludağ University \\ Faculty of Theology \\ Basic Islamic Sciences, Department of Exegesis (Tafsir) \\ Turkey
}

\begin{abstract}
al-Maturidi puts forth that "truth" is the only factor that will enable the human kind to live perfectly in all areas; emphasizing the threat of "taqlid" that may hinder humankind to reach the truth before it can even determine the methods to do so, thus trying to prevent from the outset the sacrificing of the efforts that may be put forth to reach truth in favor of mistakes that are adopted blindly. According to al-Maturidi, the only way to reach truth is correct information acquired based on evidence. The way to reach this knowledge is through the use of reason. al-Maturidi accepts that the mind can apprehend everything that falls into the category of objects or things (all creatures and events) either by way of the results put forth by the senses or by pondering on the sensory knowledge through evidence put forth by way of "nazar". His idea that truth and the correct information based on evidence that is required for accessing truth can be put forth in an objectivity that shall enable everyone to accept it is actually a very important principle. Accordingly, an understanding of knowledge and istidlâl (deduction) method lie at the foundation of the world of thought of al-Maturidi. Therefore, al-Maturidi 's understanding of religion in general and specifically his understanding of Qur'an are appearances that tower over his understanding of knowledge. Hence, it can be stated that the wisdom of al-Maturidi in tafsir is quite methodical. Here, we shall try to put forth the theoretical basis of the dirâyet method of al-Maturidi in tafsir with tangible manifestations set forth as examples. The fact that al-Maturidi has carried out his scholarly activities based on such a method is in our opinion an indispensable part of the scientific and cultural treasure of Islam. It is understood from the references in his works that the understanding of science in that era and especially the climate set forth by Mu'tazila ulema (scientific/systematic discourse) is very effective in alMaturidi's efforts to place this important principle, that is the "scientific method", which will give birth to the institutionalization that shall enable humankind to meet with beneficial principles.
\end{abstract}

Keywords: al-Maturidi, Tafsir, Method, Reason, Hikmah/Wisdom, Haqq/Truth, Evincing

The exegesis methodology of al-Maturidi can become comprehensible only after an analysis of his theory of religion. Indeed, his methodology is a kind of useful instrument to provide problems (man, universe, Allah, afterlife, book, prophethood, worship, rituals, morals etc.), which constitute his theory of religion, with a regular, consistent and meaningful character. When it comes to theoretical perspective, a theory in natural sciences can establish itself as valid and therefore scientific only if it can put forth all relevant issues as a meaningful whole, ensure prevention of their falsification by virtue of past, present or future phenomena, and make them comprehensible and explainable for man; thus, this is the only way to generate correct and accurate knowledge to serve for human affairs and interest; likewise, the validity and scientific quality of a religious theory, one of the most comprehensive disciplines of humanities, depends on whether such theory establish a method so as to make relevant issues and phenomena meaningful elements and to generate modes of knowledge and acts which can provide man with contribution and interest. Indeed, a theory has the power to determine all aspects of human life as soon as it is incorporated by the latter. Any abstract and concrete crop, also known as culture, which begin with modus operandi of mind in such manner to include human acts to appear on the basis of knowledge generation style and generated knowledge, is a consequence of the theory adopted in the beginning. Accordingly, it is vital to put forth a theory capable for ensuring gathering the institution of religion with man in both scientific terms, namely, in terms of humanities, and also with regard to future of man. In this respect, al-Maturidi is not a man of knowledge, but a scientist with strong theoretical capabilities; indeed, history has paid homage to him, by naming his theory, which constitutes the spirit of his works, as "Maturidiyya".

A profound analysis on theory of religion by al-Maturidi will better clarify his exegesis method; accordingly, the principle, which enables him to make each religious issue meaningful/erudite elements for man and to reveal that all religious issues are interconnected through a meaningful relation based on wisdom, is a rational/theoretical principle expressed by term "haq/haqiqa" ("true/truth"). 
Since this principle of "true/truth", which will be explained below is a rational/theoretical/behavioral with regard to its existence within man, al-Maturidi tries to put man and human reason in the center as much as possible while explaining the problems within the course of constitution of his theory. Thus, his theory as a whole and ideas constituting this theory can become comprehensible and obtain evidential nature.

For instance, in his explanation about meaning of the term "mansur", al-Maturidi clarifies why both he and his method are called "Abû Mansûr", indicating that his method of deduction is actually the method employed by prophets. For him, "nasr" means rendering truth, which exclusively possesses evidential quality, the right of a person who puts forth and defends truth; besides, a person, who puts forth and defends truth despite any difficulty, is called "mansur" in the sense of absolutely unbeatable victorious (al-Maturidi, 2004: I, 58). Al-Maturidi does not ground religious issues on the power of any authority so as to make in meaningful and acceptable; instead, he chases the truth with evidential quality and adopts an approach/presupposition in such manner to render religious issues meaningful and acceptable by means of authority of truth; this is because it is impossible for al-Maturidi to deem religious issues incomprehensible for their addressees, namely, man; indeed, the prerequisite for any human duty is, above all, comprehension of such duty, since it would be nonsense/unwise to expect man to fulfil something he cannot understand (al-Maturidi, 2005b: 209).

The principle of "true/truth", which enables al-Maturidi to provide his thoughts on religion with philosophical aspect, is manifested in rational/theoretical man who also has metaphysical and existential quality; this moral/actual principle finally becomes visible in the acts/deeds of man. As for how hereby principle appears in human beings, this principle is "rational" since "reason" is the means through which this principle meets man, "theoretical" since one can attain it through the known, in other words, sensitive knowledge, "epistemological/behavioral" since it exists within human mind as knowledge, and finally, "moral/actual" since it holds man responsible for voluntary acts that have to be carried out pursuant to relevant knowledge in human mind. According to al-Maturidi, it is God who brings man together with this principle; therefore, he considers God as the origin of truth; the cause of such meeting is trying man and the eventual acquisition of deserved return.

Following the general description above, we will try to explain how this principle became known for man, sin other words, earned the quality of knowledge. Al-Maturidi describes the principle of "true/truth" with the terms "وضع الثيء "موضعه; that is "to rule (waz") something in where necessary" (al-Maturidi, 2004: I, 234, 277, 302-303, 314, 448, 529; II, 44; V, 242; al-Maturidi, 2005a: I, 234; XVI, 85), and defines the concept of "wisdom" as accuracy of such deed (alMaturidi, 2005b: 487-488, 152; al-Maturidi, 2004: III, 7; I, 96, 369, 529, II, 134, 389). The style of act, expressed as "waz" in the foregoing definition, indicates "to know", "to rule/make a judgment", "to act" on the part of a person who displays such behavior through mentioned deeds; accordingly, the definition implies "to know something as it should be known", "to make a judgment about something as necessary" and "to do something as necessary"; this definition corresponds to rational category of "vujub" (obligation); hence, al-Maturidi acknowledges that all religious orders and prohibitions, more precisely, all orders and prohibitions about faith, worship, morals, procedures and punishments appear in the form of obligation pursuant to rational requirement (al-Maturidi, 2005b: 274). Therefore, he considers reason, which enables coming together of man and the institution of religion, as the most important means of understanding. Moreover, al-Maturidi thinks that hereby function of ruling of reason makes existence of truths, therefore, religion and test, possible for humans. Consequently, the existence of the principle of true/truth depends on existence of ruling function of reason; this is why it is possible to assert that the principle of true/truth is a form/template attributed to reason, the means of human understanding, by the Creator. When the problem is put under the microscope to see the relation between reason, the most valuable means of human understanding, and elements of waz' (الوضع) in the definition of true/truth, ruler (wazi') (الواضع) that is binding for ruling, as well as 'the matter subject to ruling' (mawzu') (الموضوع) and 'correct judgment' (mawzi) (الموضع), we find out reason is in position of ruler and its function is the activity of ruling; it encodes anything it comes across as a matter subject to ruling and ordains a correct judgment for it. Therefore, anyone, who possesses the means of reason, necessarily and inevitably ordains a correct judgment about each matter he comes across thanks to his reason capable of ruling and gives a ruling. Indeed, according to al-Maturidi, the reason, which is the means for ruling, is rendered existent within man as an automatically functional faculty (al-Maturidi, 2005b: 158, 280); in other words, the instrument of reason obligatorily generates and puts forth for man the knowledge which should be known; likewise, it prepares and presents to man the judgment and act which should be passed or performed; therefore, reason is the element which necessarily makes man subject to proposition. Organs and limbs, which are rendered existent in human body in an automatically functional manner so as to meet his physical requirements, run necessarily as instruments for fulfilment of physical and material interests; similarly, reason is considered as the most important and most valuable instrument that allows man to meet his spiritual requirements and to know necessarily what is true/good/right in matters he is subject, to realize them and therefore to deserve maturity. 
Considered as instrument of ruling, reason fulfils its function in relevant matter by carrying out the activity of ruling through determination of a correct ruling for each matter; any assessment on accuracy of the consequence of such activity requires distinction of two following aspects of the problem. Firstly, there is a single truth, in other words, a single correct judgment for each available ruling for every individual capable of ruling and that brings together every rational person about relevant matter.

This aspect is beyond interest of individuals or classes and comprises the quality to establish affairs and interests of all humans, namely, to preserve the law; consequently, the consequence of mentioned act of ruling puts forth the absolute truth about relevant matter. In this regard, there is a single correct judgment in each matter in need of ruling; the correctness of ruling depends on whether the ruling to be passed by ruler is carried out in line with the only correct judgment about relevant matter.

For instance, al-Maturidi analyzes the practice of consensus (ijma) within this framework and thinks that truth enables formation of the institution of consensus, which is very important for the social species called man. Through another perspective, consensus is a function attributed on truth, which is attainable through reason, by God, since it bears evidential quality on humans, is obligatory to be accepted and finally contributes to continuity of human species under ideal conditions; accordingly, al-Maturidi evaluates consensus as a grace and help of Allah to man (al-Maturidi, 2005b: 14-15). At this point, it is worth noting that for al-Maturidi, consensus, which bears evidential quality and has to be accepted, is not merely coming together and agreement on a judgment of those who pass such judgment; instead, those who pass judgment have to be competently fair and ensure concord about relevant judgment since it will comply with truth and justice. Therefore, consensus becomes evidential as Shar'i (judicial) evidence thanks to quality of justice/truth born by those who pass such judgment (al-Maturidi, 2005a: I, 260-261 ). Given that Allah is the source of truth and justice, we can understand why al-Maturidi attributes the consensus, namely, the unity ensured by a true and just judgment about an issue, to Allah and considers it as divine grace. Al-Maturidi deals with the problem in his

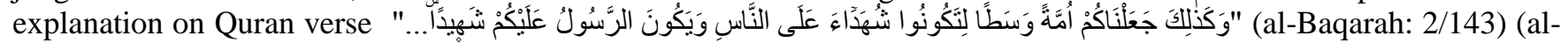
Maturidi, 2005a: I, 260-261; Bilgin, 2012: 193-195).

The practice of abrogation (nash) can constitute another example. By means of this principle, al-Maturidi apparently abolishes the alleged contradiction between different judgments on the same issue and thus gathers and unifies Quran verses, judgments and even laws. For al-Maturidi, abrogation means continuation of validity of passed judgment as long as the existence/conditions of matter, which lays foundation for judgment, are present, and passing of a new judgment, which should be put into force instead of a defunct judgment through a new ruling. Therefore, the judgment, passed about previously about a matter in its specific conditions, and the judgment, which should be passed about the same matter albeit changing conditions after the initial judgment, may be apparently different; nevertheless, both judgments are one and same in terms of bearing the quality of true/truth for man since they prevent any harm and secure possible benefits for man (protect rights of man) under their respective time and conditions (Bilgin, 2012: 120127). Accordingly, the emergence of judgments, which are the ground for existence the religious concept of unity (tawhid) within man, in different periods throughout history better clarifies its quality to establish unity within man and the unity within the family of mankind.

Secondly, the problem has an individual and particular aspect, not in parallel with absolute truth. Each ruling, which is performed by ruler through consideration of correct judgment for each emerging matter, is a consequence arising from personal thoughts and value judgments of ruler and it is nothing but a judgment about correct ruling deemed appropriate by ruler about a certain matter; nevertheless, this judgment cannot be necessarily true or accurate only because such ruling complies with the personality and attitude of ruler in face of incidents and situations, or even with his world of values and thought about relevant matter. Individual and personal pertinence or arbitrariness is not the decisive element for accuracy of ruling; in other words, the prerequisite is not to ensure interest of a certain person, class or nation, but to serve common interest of everyone, in other words, to preserve rights of everyone. Indeed, given the consequence/interest provided for the individual to carry out ruling, a faculty peculiar to man (it is a compulsory attribute of ruling that it is realized for obtaining an interest), the individual has to choose either his own interest or interest of others prior to any ruling to be performed. The authentic reason and religion considers human benefit in macro scale and calls man to act pursuant to reason/wisdom, namely, to give a ruling in purpose of securing common interest; indeed, the preservation of interest and rights of individual depends on provision of common interest and benefit of society/family of mankind (Bilgin, 2012: 202-204).

As for direct relation between the foregoing matters about al-Maturidi's methodology and Quran and exegesis, alMaturidi thinks that Quran tells how humans should give ruling about all beings and incidents and allows for methodology and knowledge about how they should understand things and locate them in a consistent manner pursuant to a hierarchy within their world of thought. 
According to al-Maturidi, such knowledge includes all benevolence about worldly and future life; therefore, such knowledge of truth/wisdom bears the quality of various benevolence, in other words, comprises all beauties that are truly valuable for man. This is the essential meaning behind self-qualification of Quran as wisdom, light, true path, soul, and heal.

In this context, Quran is qualified as light (nur) (an-Nisa: 4/174) for it is the source of clarifying knowledge about how to understand and locate all beings and incidents and how to act (حقائق الأثناء), as "true path" (hidayah) (al-Baqarah: 2/2) for everything is understood through it and any avoidance of harm is possible thanks to it, as "soul" (ruh) (ash-Shu'ara: 42/52) for each owner of soul comes to life through soul, and as "heal" (shifa) (al-Isra: 17/82) since it enables avoidance of any evil situation (al-Maturidi, 2004: I, 277). ${ }^{1}$ Therefore, as al-Maturidi clearly indicates, the activity of exegesis (tafsir) will be the activity to reveal such truths contained by Quran verses (al-Maturidi, 2004: I, 462, 343346). An exegesis pursuant to mentioned approach is the only way to correct understanding of the present and the unseen, the being and the incidents, as well as judgments about them by means of true religion and reason.

As for importance of reason and its ruling function for al-Maturidi, he refers to three essential issues in his establishment of the institution of religion, namely, divinity, prophethood and afterlife; then, he recourses prophethood and afterlife to divinity, and divinity to existence and unity of God; thus, he grounds the foundation of religion on the approving acceptance of existence and unity of a metaphysical being; in other words, the first step to allow man through the gates of religion, and therefore the point of departure for religious offer, is approval by man of existence and then unity of a metaphysical being, namely, God. According to al-Maturidi, reason is the only means to ensure realization of foregoing phase, in other words, to enable man attain knowledge of existence and unity of God and come together with the institution of religion; the realm of existence, which is also known as universe and where man is present, is the only means to enable reason attain knowledge of existence and unity of God. Indeed, for al-Maturidi, it is impossible to know God through senses or testimony of tradition and God cannot be known except for knowledge of universe as His evidence; the only way to know God is the theory and deduction, the functioning principle of reason (al-Maturidi, 2005b: 193-194, 199, 372; al-Maturidi, 2005a: V, 167; al-Maturidi, 2004: II, 156). ${ }^{2}$ If deeds are the main source to get to know a person, then, the way to ensure knowledge of God is universe, the output of His deed; universe, as the name implies, is the realm of existence pointing out to the one who created it; the only means to know the meaning of these signs (ayat, dala' $i$ ) and to recognize the pointed out is reason, while the methodology is theory and deduction. As for ways of attaining the knowledge on existence and unity of God, al-Maturidi asserts man feels or senses the beings and incidents in universe, where he is present, through his senses, namely, his means of understanding; then, the reason, which is the other means for understanding, operates on the verified sensual knowledge and generates knowledge about non-sensual/hidden/rational through evidence of sensual knowledge (dalalah ash-sha'hid ala'l-ghaib). Therefore, the presence of a religiously objective and generally acceptable method is proven through the rule that one has to ground on beings and incidents in the universe of the present in order to reveal whether an alleged knowledge about the hidden is correct. Accordingly al-Maturidi grounds on the universe and eventual emergence of universe in order to explain existence of Allah, and opts for compulsory rational deduction that the created being necessitates a creator (al-Maturidi, 2005b: 25-29, 34-36; al-Maturidi, 2004: V, 199); likewise, man makes use of epistemological instruments and generates knowledge as a result of his relation with beings in the universe of existence, and the acquired sensual knowledge leads one to generate rational/theoretical knowledge that necessitates acknowledgement of existence and unity of God (al-Maturidi, 2005b: 216, 372; al-Maturidi, 2004: IV, 585; Bilgin, 2012: 202-204).

In order to comprehend the theory of religion and exegesis methodology of al-Maturidi, it is crucial to understand that he often allocates a leading role to man and human reason. A general description on backbone of his manner of thinking will demonstrate the accuracy of foregoing determination. According to al-Maturidi, man is a being created as incomplete in material and immaterial terms; the principle to ensure his maturity in meeting such requirements is the principle of truth which he should realize through willed acts; knowledge is the only means to bring man together with truth; the source of knowledge is the realm of existence, namely, universe where man exists; the instruments to provide knowledge which will make man attain truth are senses and particularly the reasons; types of knowledge, which is obtained via mentioned instruments, are sensual, rational and reported knowledge;

1 The explanations quoted by al-Maturidi reveal earlier scholars adopting the same approach. Also see al-Maturidi, 2004: I, 227, 277, 299, 302-303, 314, 344-345, 369, 448; IV, 579; V, 242.

2 Quoted from al-Maturidi, 2005a: V, 167

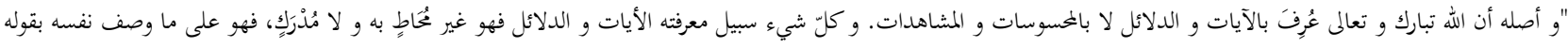

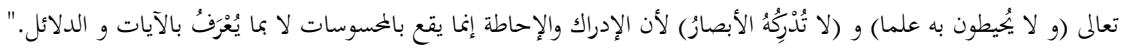


The ways to obtain knowledge can be classified as follows: First, direct knowledge about things when there is no obstacle between senses and things in terms of time or space (such knowledge is sensual knowledge and constitutes the essence and source for human world of knowledge since they are exact and obligatorily acceptable); secondly, generation of knowledge about something that is distant/hidden to senses because of an obstacle in terms of time or space, through reference to evidential quality of initial sensual knowledge (dalalah ash-sha'hid ala 'sh-sha'hid);

Thirdly, knowledge about things that are impossible to sense because of their content (ghaib) via reference to evidential quality of exact sensual knowledge (dalalah ash-sha'hid ala'l-ghaib); and finally, knowledge about issues where there is difference between the present and hidden because of various aspects of wisdom, without direct reference by reason to evidential quality of the present. At this stage, it is important to indicate that since the issues, which constitute the institution of religion, are rational/theoretical, it is reason which enables existence of such issues for man and these issues are based on the principle of understanding; indeed, given that the problems about particular issues in religion are grounded on procedural topics, we can observe the effort to establish entire institution of religion in the axis of reason. According to al-Maturidi, the rational/hidden knowledge about existence and unity of God, which man can attain in the wake of his observations of universe, eventually leads to birth of the knowledge regarding human duty of gratitude towards God (al-Maturidi, 2004: I, 344); this knowledge and judgment, attained through reason, makes the religion and all religious orders and prohibitions, particularly the worship, meaningful, acceptable and realizable for a person. Once man attains the knowledge/judgment/ruling about duty to offer his gratitude to Allah, he reaches the process of implementation of such gratitude; thereupon, reason attains the knowledge and judgment that gratitude can be realized only through acts/deeds, more precisely, obedience to orders and prohibitions by Allah and avoidance of sins or disobedience.

In addition, al-Maturidi indicates that universe operates on three essential procedures, namely, obligatory (wajib), contingent (mumqin) and impossible (mumtani); reports/revelations cannot arrive in obligatory and impossible manner, but only in contingency in rational terms; accordingly, for al-Maturidi, prophets explain the most appropriate situation among alternatives about each circumstance in the realm of contingencies, in other words, the realm of change and alternatives (al-Maturidi, 2005b: 282). ${ }^{3}$ Thus, he explains the mission of prophethood in rational terms and describes prophets as personalities who invite to matters that are possible to indicate for human reason or that are rationally explicable (al-Maturidi, 2005b: 293). As for religious texts, he states أنه جمعها (أي الحروف) على ما توجبه الحكمة" (alMaturidi, 2004: III, 39); that is, he agrees that revelation and composition of divine books in general and Quran in particular, takes place pursuant to wisdom (obligation).

In another example, al-Maturidi states that piety can be easily realizable for man only through reasoning. More precisely, man moves away from piety because of his worldly desires and wishes, which can be avoided only through the facts obtainable by reason in case one thinks thanks to Who his existence began and to Who he will return, as well as all stages of his life; consequently, such rational facts will lead man to piety, in other words, these facts will easily protect man against impulse stimulated by worldly pleasures and material interests despite sedition caused by such pleasures towards misconduct (al-Maturidi, 2004: I, 311-312).

For al-Maturidi, Allah Ta'ala instilled the thought of justice and the principle about its goodness into human reason as an essential tenet; in line with this structure, human reason points out to order anything which bears the quality of fairness and to prohibit anything that lacks such quality, in other words, that means persecution (al-Maturidi, 2005b: 274; al-Maturidi, 2004: I, 169). Therefore, it is necessary for al-Maturidi to explain the fairness and justice of orders and prohibitions pursuant to the fact that a subject shall prefer and realize what is fair and just within his realm of will and power, since man, in line with the principles instilled in his reason, follows the ordering and prohibiting path of such principles.

The methodology of wisdom based on theory and deduction by al-Maturidi also emerges in problems directly related with the area of procedures or human deeds; in this regard, each relation man, as a social being, enters with others, necessitates existence of issues/topics about which correct/true judgments is required and thus judgment/ruling about each issue. Therefore, the provisions in Quran verses about deeds are evaluated as correct judgments/rulings with the quality of truth and wisdom about certain topics subject to ruling (Bilgin, 2012: 319-330).

3 Quoted from al-Maturidi, 2005b: 282:

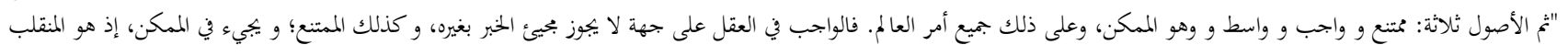

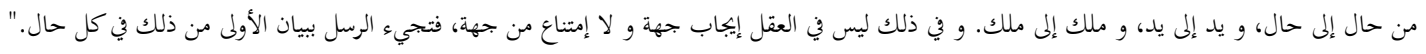


For example, al-Maturidi puts forth importance of the concept of testimony by laying stress on its wisdom; accordingly, testimony enables avoidance of deprivation of rights among people due to oblivion, mistake, doubt, suspicion or denial and ensures sustainability of relations between the members of society, as well as of social order; one should give testimony only for Allah Ta'ala, even if such testimony is against himself or his parents (al-Maturidi, 2004: I, 238-239, 513-514; V , 159, 254); indeed, preservation of individual rights is possible only if he lives in a social order.

As a final example, we can cast a glance upon the concept of trial, an important concept in the theory of religion by alMaturidi, in order to see how he renders the phenomenon of trial and other significant religious issues in the axis of reason through his methodical perspective.

With regard to Quran verses about trial of man, al-Maturidi concentrates on freedom and responsibility of man in terms of will and deeds, indicating that all creatures, in other words, universe, is created for trial of man (al-Maturidi, 2005a: II, 512; al-Maturidi, 2004: I, 22, 29) to underline the importance of the question. The idea of trial has a central part in his system of thought. Indeed, for al-Maturidi, the human will and freedom of deed is what corresponds to the truth of trial and what provides meaning for wisdom of Allah, creation of universe, existence of religion, institution of prophethood, revelation of religious texts and existence of afterlife (al-Maturidi, 2005b: 130, 252-253, 460; alMaturidi, 2004: I, 100, 159); in his exegesis of certain Quran verses, he attaches striking importance to human deeds within the scope of mentioned concept of trial. According to al-Maturidi, the following verses

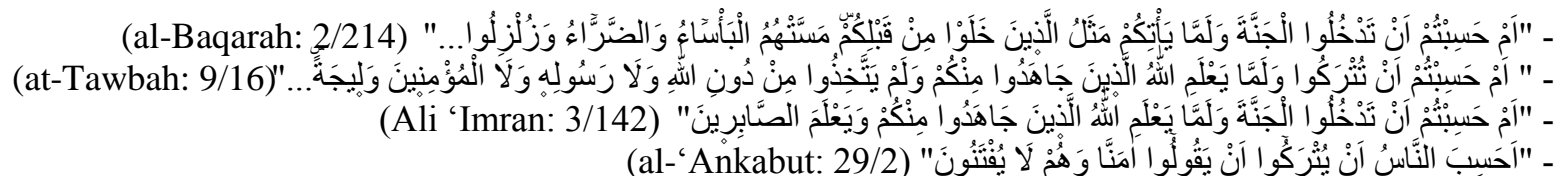

report inevitability of trial and difficulties in faith; faith is not difficult in itself, because faith is true knowledge and true word; accordingly, there is no difference between true word and false word or true knowledge and false knowledge in terms of difficulty, since neither pole brings along any difficulty in terms of obtaining knowledge or expressing such knowledge; therefore, faith emerges as opposition by man against his nature and self, and trial will take place in various forms (al-Maturidi, 2004: I, 159). Accordingly, al-Maturidi divides the existential levels of man in face of truth in three: to know (ma'rifat), to express what he knows ( $q a w l$ ), and to act against the wishes of his self and nature; the trial, which incorporates certain trials and difficulties, is realized by acting against one's nature and self, and not at the level of knowledge or expression of knowledge.

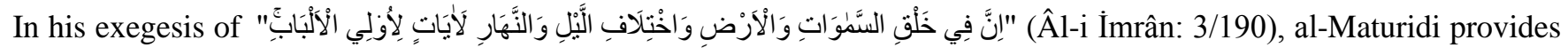
another significant explanation about the matter. For him, man is not created to know the difference between wisdom and unwisdom, guardianship and enmity, good and evil, demand and avoidance; if man were created for such purpose, truth/wisdom would be lost, whereupon creation of man would be meaningless; therefore, the true deed in terms of reason and wisdom is actual distinction between foregoing concepts; any opposite situation would contradict the purpose of creation of man, in other words, the spirit of trial, and therefore point out to unwisdom; however, it is impossible that Allah Ta'ala, who bears the attributes of wisdom and justice, can create such an unwise order. In the end, all creatures are created for trial of man, and trial means testing man about whether he can fulfil requirements of justice and wisdom about mentioned issues that require actual distinction. Al-Maturidi refers to divine attributes for justification of his argument and asserts that the names 'Wise' and 'Utterly Just' of Allah necessitates such realization of trial (al-Maturidi, 2004: I, 344).

The importance attached by al-Maturidi to trial of man is visible in his indication of trial as a principle of consideration in understanding and interpretation of Quran verses. For him, meanings ascribed to Quran verses should be evaluated in such manner to incorporate the truth of trial of man, rather than excluding this fact (al-Maturidi, 2005a: II, 234). Besides, Quran verses about prophets should be understood in such manner that even they are subject to trial and not as in a way to abolish trial and offer (al-Maturidi, 2004: I, 243). On the other hand, al-Maturidi evaluates another according to which if a slave does not know his deeds will irritate his master and this is considered as an acceptable excuse in terms of wisdom, then why, if a man does not know orders of Allah or meaning of such orders, such lack of knowledge cannot constitute an excuse to relieve him from any penal responsibility. In his regard, al-Maturidi gives significant explanations about the person subject to trial and the place and importance of deduction in process of trial. First of all, he clarifies differences between of relation of slave-master and the relation between man and Allah, and asserts such example is incapable for verifying relevant argument. Accordingly, the excuse that slave does not know his deed will anger his master is valid for the salve only in case there is no evidence that his master will dislike such deed; nevertheless, the evidence/signs about how his deeds will be received by Allah are rendered available for man. 
Indeed, the faculty of deduction, which is the human capacity to observe, read and understand such evidence present in himself, as well as surrounding incidents, and structures and behaviors of beings subject to his observation, nullifies the possibility of a valid excuse. Allah Ta'ala creates an evidence in company of everything He orders to His subjects; in other words, He creates the evidential elements that enable knowing the meaning and possible consequences of such orders; besides, He stimulates human mind through thoughts and inspirations, and warns it through various lessons. Therefore, when man displays a behavior contrary to divine consent, such behavior can exclusively originate from abandonment of deduction (theory, observation) and of reasoning, which is a deed that exclusively belongs to subject; therefore, such behavior lacks any valid excuse or justification and proves his own sentence (al-Maturidi, 2005b: 209).

It is worth repeating that for al-Maturidi, the trial is possible essentially because man has freewill and therefore is free in his choices; accordingly, trial will be abolished in case freewill is disabled and an obligatory situation occurs (alMaturidi, 2004: IV, 502). Indeed, trial explicitly takes place within an equilibrium between reason and self. An obligatory situation will unbalance this equilibrium, whereupon the trial will become meaningless. Pursuant to such view, al-Maturidi defines trial as the struggle between reason and self. Reason invites self or vice versa; when reason invites self, it calls the self to what will be obtained in the end and what looks good to reason (in other words, what is valuable in itself), whereas self invites reason to inferior desires and pleasures (al-Maturidi, 2004: V, 511; Bilgin, 2012: 243-247). Accordingly, the duty of man to obtain his merited reward is to leave what self desires and to realize what reason wants. In this regard, al-Maturidi explains the problem of "ascent of Allah to heaven" with "creation of man, namely, the being to be held responsible for trial"; the emergence of sovereignty, superiority and sublimity of Allah will be realized through creation of man who will be tried by means of the faculty of ruling, since the intent in creation of heaven and earth is man. Thus, the element, which renders entire creation wise/true, is creation of man as free, reasonable being (al-Maturidi, 2005b: 113-114; Bilgin, 2012: 137-146). Finally, all the foregoing demonstrates that alMaturidi builds his theory of religion on the principle of true/truth which is attainable exclusively through reason, and that he tries to understand and explain all religious question by means of the mentioned method.

\section{Bibliography}

Abû Mansûr Muhammad b. Muhammad b. Mahmûd al-Samarkandi. (2004). Tafsir al-Qur'an al-Azim al-Musamma Ta’wilat Ahl al-Sunnah (Volume I-V. Edit: Fâtıma Yûsuf el-Haymî). Beirut: Muassasat ar-Risala.

al-MATURIDI, Abû Mansûr Muhammad b. Muhammad b. Mahmûd al-Samarkandi. (2005a). Ta'wilat al-Qur'an (Volume I-XVIII. Edit: Ahmed Vanlığlu). Istanbul: Mizan Yayınevi.

el-MATURIDI, Abû Mansûr Muhammad b. Muhammad b. Mahmûd al-Samarkandi. (2005b). Kitab al-Tawhid (Edit and Footnotes by: Bekir Topaloğlu, Muhammad Aruçi). Ankara: İsam Yayınları.

BİLGIN, Ö. F. (2012). El-Matürîdî'nin Te'vîlâtü'l-Kur'ân'ının Dirâyet Tefsiri Açısından Tahlili (PhD Dissertation), Uludağ University, Bursa. 